\title{
Survei Kualitas Air Danau Pandan yang Terletak di Kecamatan Pinangsori Kabupaten Tapanuli Tengah
}

\author{
Pandan Lake Water Quality Survey has Located in Pinangsori \\ Sub-District, Central Tapanuli District
}

\section{Dian Fitria $\mathbf{M}^{1 *}$, Rosmasita ${ }^{2}$, Emma Suri Yanti ${ }^{3}$ Insaniah Rahimah ${ }^{3}$, Ramona Indah Bagariang ${ }^{1}$}

\author{
${ }^{1}$ Jurusan Akuakultur, Sekolah Tinggi Perikanan dan Kelautan Matauli, 22611, \\ Indonesia \\ ${ }^{2}$ Jurusan Teknologi Penangkapan Ikan, Sekolah Tinggi Perikanan dan Kelautan Matauli, 22611, \\ Indonesia \\ ${ }^{3}$ Jurusan Sosial Ekonomi Perikanan, Sekolah Tinggi Perikanan dan Kelautan Matauli, 22611, \\ Indonesia
}

*Korespondesi: dianfitria.manurung@gmail.com

\begin{abstract}
ABSTRAK
Danau pandan memiliki luas \pm 103 Ha yang terletak di desa Parjalihotan Baru kecamatan Pinangsori kabupaten Tapanuli Tengah. Status keberadaan danau pandan masih jarang diketahui oleh masyarakat Tapanuli Tengah maupun masyarakat luar dari kabupaten Tapanuli Tengah, sehingga penelitian mengenai danau pandan masih jarang dilakukan. Tujuan penelitian ini adalah untuk mengetahui kualitas air danau pandan yang diamati dari parameter fisika yaitu suhu dan kedalaman, sedangkan parameter kimianya mengamati kandungan $\mathrm{pH}$ (Potensial Hidrogen) dan DO (Dissolved Oxygen) perairan, serta mengetahui kondisi hidrologi dari danau pandan tersebut. Hasil pengukuran suhu air danau pandan selama penelitian memperlihatkan bahwa suhu air pada 10 titik stasiun berkisar antara $32,0^{\circ} \mathrm{C}-36,0^{\circ} \mathrm{C}$, sedangkan kedalaman danau berkisar $0,8 \mathrm{~m}-1,7 \mathrm{~m}$. Nilai DO atau kandungan oksigen terlarut perairan danau pandan kisaran dari 4,91 mg/l - 9,03 mg/l. pH air danau Pandan berkisar antara 6,8 - 9,02. Kondisi hidrologi Danau Pandan dibentuk oleh aliran parit-parit dan sungai yang yang bermuara ke Danau Pandan antara lain: Sungai Aek Kemuning dan Aek Lobu. Sedangkan outlet Danau Pandan secara alami mengalir ke arah utara melalui Sungai Aek Kemuning dan bermuara ke Desa Sitardas, Badiri Tapanuli Tengah.
\end{abstract}

Kata kunci: Survei, Kualitas Air, Hidrologi, Danau Pandan

\begin{abstract}
Lake Pandan had an area of \pm 103 hectares located in the village of Parjalihotan Baru, Pinangsori sub-district, Tapanuli Tengah district. The status of Lake Pandan was still rarely known by the people of Central Tapanuli and outside communities of the Central Tapanuli Regency, so research on Lake Pandan was still rarely done. The purpose of this study was to determine the water quality observed from the physical parameters of temperature and depth, while the chemical parameters observed the $\mathrm{pH}$ and DO (Dissolved Oxygen) in waters, and to know the hydrological conditions of the lake pandan. The results of the measurement of Lake Pandan water temperature during the study showed that the water temperature at 10 station points ranged from $32.0^{\circ} \mathrm{C}-36.0^{\circ} \mathrm{C}$, while the depth of the lake ranged from $0.8 \mathrm{~m}-1.7 \mathrm{~m}$. DO value or dissolved oxygen content of lake pandan waters range from $4.91 \mathrm{mg} / 1-9.03 \mathrm{mg} / 1$. Lake Pandan water $\mathrm{pH}$ ranges from 6.8 to 9.02 . The hydrological condition of Lake Pandan was formed by the flow of ditches and rivers that flow into Lake Pandan, among others: Aek Kemuning River and Aek Lobu River.
\end{abstract}


While the Lake Pandan outlet naturally flows northward through the Aek Kemuning River and empties into Sitardas Village, Badiri Central Tapanuli.

Keywords: Survey, Water Quality, Hydrology, Lake Pandan

\section{PENDAHULUAN}

Kabupaten Tapanuli Tengah terletak pada $1^{\circ} 11^{\prime} 00^{\prime \prime}-2^{\circ} 22^{\prime} 00^{\prime \prime}$ Lintang Utara dan 9०07'00" $-98012^{\prime} 00^{\prime \prime}$ Bujur Timur. Letak geografis Kabupaten Tapanuli Tengah memiliki batas - batas seperti bagian utara Provinsi Nangroe Aceh Darussalam, bagian selatan Kabupaten Tapanuli Selatan, bagian barat Kota Sibolga dan samudera hindia, dan bagian timur Kabupaten Tapanuli Utara, Kabupaten Humbang Hasundutan dan Kabupaten Pakpak Bharat. Tapanuli Tengah juga terletak di pesisir pantai barat pulau sumatera dengan garis pantai sebesar $200 \mathrm{~km}$ dan sebagian wilayahnya berada di daratan pulau sumatera serta sebagian lainnya di pulau - pulau kecil. Selain itu Tapanuli Tengah merupakan daerah yang memiliki hamparan gunung, pantai, laut dan sungai (BPS Tapanuli Tengah 2018).

Kabupaten Tapanuli Tengah terdiri dari 20 kecamatan, yaitu Sirandorung, Manduamas, Barus Utara, Andam Dewi, Sosor Gadong, Barus, Pasaribu Tobing, Sorkam Barat, Sorkam, Kolang, Sitahuis, Tapian Nauli, Tukka, Sarudik, Pandan, Sukabangun, Badiri dan Pinang Sori (BPS Tapanuli Tengah 2018). Pemerintah Kabupaten Tapanuli Tengah (2020) manyatakan secara umum beberapa kecamatan tersebut memiliki potensi wisata alam yang terdiri dari: pantai, pegunungan, alam perbukitan bukit barisan, kawasan hutan lindung batang toru, air terjun, sungai-sungai dan danau. Tapanuli Tengah memiliki danau yang sering disebut sebagai danau Pandan. Masyarakat setempat yang hidup disekitar danau pandan yang menentukan nama danau tersebut dengan mengambil salah satu flora yang dominan hidup di pinggiran danau berupa tumbuhan pandan. Danau Pandan terletak di Kecamatan Pinangsori. Danau ini berlokasi tidak begitu jauh dari bandara
Ferdinand Lumban Tobing, yang merupakan kebanggaan masyarakat Kabupaten Tapanuli Tengah sebagai salah satu akses melalui udara jika kita berkunjung ke daerah Tapanuli Tengah dan sekitarnya.

Hasil Musyawarah Perencanaan Pembangunan / Musrenbang Kabupaten Tapanuli Tengah 2018 melahirkan 8 (delapan) program prioritas dalam rancangan Pedoman Penyusunan Rencana Kerja Pembangunan (RKPD) tahun 2019 sesuai yang tercantum pada Rencana Pembangunan Jangka Menengah Daerah (RPJMD) Tapteng Tahun 2017-2022, diantaranya adalah pembangunan sarana dan prasarana destinasi wisata serta peningkatan promosi dan daya tarik wisata Tapanuli Tengah. Rapat Tim Pengendali Mutu dan Tim Peneliti Kajian Sumber Daya Alam dan Kajian Sosial Ekonomi membahas dan memutuskan rencana pengembangan kawasan Danau Pandan yang terletak di Desa Danau Pandan, Kecamatan Pinangsori, Kabupaten Tapanuli Tengah menjadi salah satu destinasi wisata tambahan di kabupaten ini selain destinasi wisata pantai dan wisata religi yang sudah ada.

Sebagai satu-satunya danau yang berada di kabupaten ini, Danau Pandan diperkirakan menyimpan banyak potensi layaknya danau-danau yang ada di Indonesia. Sumberdaya perairan Danau Pandan masih tergolong alami, karena relatif jauh dari aktivitas masyarakat sekitar / para urban dan masih belum termanfaatkan sampai saat ini. Selain tujuan dari Musrenbang Kabupaten Tapanuli Tengah menjadikan Danau Pandan sebagai destinasi wisata, danau ini juga diharapkan dapat dimanfaatkan sebagai sumber air bersih bagi masyarakat, edukasi, dan lain sebagainya. Untuk memwujudkan hal tersebut, maka diperlukannya kajian, salah satunya adalah kajian kualitas air Danau Pandan. 
Kajian kualitas air danau baik di Indonesia maupun diluar negeri sudah banyak dilakukan peneliti sebelumnya seperti: Kutics (2019) tentang evolusi kualitas air Danau Balaton; Adeleke (2014) tentang penilaian kualitas air Danau UPM dan dampak dari Sistem Informasi Geografis; Herschy Bengtsson (2012) tentang kualitas air di danau dan waduk; Sulfikar (2013) tentang survei kualitas air Danau Arena Dayung Tanjung Bunga, Makassar; Wijaya et al (2009) tentang kajian kualitas air dan potensi produksi sumber daya ikan di Danau Towuti, Sulawesi Selatan; Krismono et al (2008) melihat karakteristik kualitas air Danau Limboto, Provinsi Gorontalo; Petri M (2006) kualitas air danau Constance namun unuk danau Pandan belum ada yang mengkaji sampai saat ini. Danau Pandan merupakan satu - satunya danau yang terletak di daerah kabupaten Tapanuli Tengah yang dapat dijadikan sebagai sumberdaya air tawar bagi masyarakat, disamping sumberdaya air laut yang sangat melimpah. Sehingga tujuan penelitian ini adalah mengetahui kualitas air danau Pandan berdasarkan parameter fisika dan kimia dasar. Peneliti berharap dengan mengatahui data sebaran kualitas air danau pandan dapat dimanfaatkan dengan baik oleh masyarakat Desa Parjalihotan yang merupakan masyarakat yang terdekat aksesnya menuju danau Pandan, serta secara umum bisa dimanfaatkan oleh masyarakat kabupaten Tapanuli Tengah maupun masyarakat dari daerah lainnya.

\section{METODE PENELITIAN}

\section{Waktu dan Tempat Penelitian}

Penelitian ini dilakukan pada bulan 04 April 2019 di 141eprese Danau Pandan Sumatera Utara, Kabupaten Tapanuli Tengah, Kecamatan Pinangsori, Desa
Pandan. Secara geografis Danau Pandan terletak pada 98 $50^{\circ} 55^{\prime \prime} \mathrm{BT}$ 98 51'53'BT dan 1'30'20" - 1'31'25' LS (Gambar 1). Danau Pandan berjarak 32,3 km dari kota Pandan, apabila menggunakan kendaraan umum dapat dicapai dalam waktu \pm 1 jam 19 menit dari Kota Pandan dan \pm 2 jam 30 menit menggunakan perahu melalui Sungai Aek Lobu Hilir.

\section{Data Lapang}

Pengambilan data lapangan dilakukan dengan metode Purposive Random Sampling. Purposive Random Sampling adalah 141epres untuk menentukan sampel penelitian dengan beberapa pertimbangan tertentu yang bertujuan agar data yang diperoleh nantinya bisa lebih 141epresentative. Berdasarkan hal tersebut, maka pada penelitian mengambil sampel dengan 10 titik stasiun uji pada jam 11.00 WIB 13.00 WIB. Stasiun ke 1 dan ke 2 merupakan perairan danau yang berdekatan dengan sungai Aek Kemuning, sedangkan stasiun 7 berdekatan dengan sungai aek lobu. Sampling yang bedasarkan pinggirian danau terdiri dari stasiun ke 3 , ke 4 , ke 5 , ke 6 , ke 8 dan ke 9. Titik stasiun ke 10 merupakan sampling pada pertengahan danau. Semua pengujian dilakukan secara in situ / pengujian langsung di lapangan tanpa pengujian di laboratorium. Pengujian perairan dilakukan berdasarkan beberapa uji fisik perairan, yaitu: Suhu, Kelarutan oksigen (Dissoved Oxygen), Derajat keasaman $(\mathrm{pH})$ dan Morfometrik berdasarkan kedalaman danau. Pengujian kualitas air berdasarkan instruksi penggunaan masing - masing alat uji yang digunakan. 

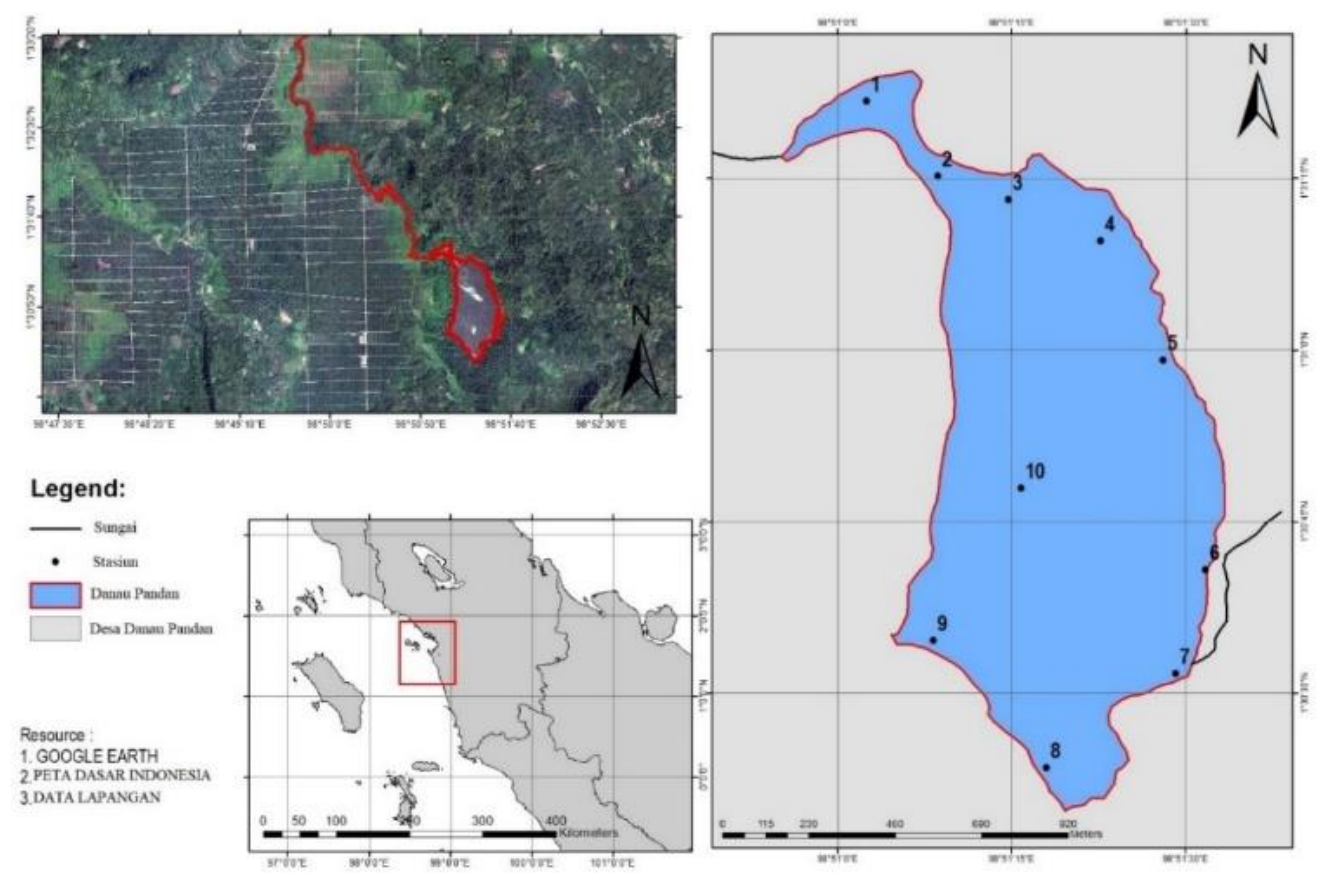

Gambar 1. Lokasi Penelitian

\section{Alat dan Bahan}

Alat yang digunakan dalam penelitian ini dibagi menjadi 2, yaitu analisis sebaran parameter Danau Pandan dan pengambilan data lapangan. Adapun alat yang diguanakan untuk analisis yaitu laptop bersistem operasi Windows 10 dan Linux yang dilengkapi perangkat lunak seperti ArcGIS 10.3. Sedangkan alat yang digunakan untuk mengambil data lapangan yaitu: GPS Garmin 78, pH Meter, DO Meter, Thermo Meter, dan Water Depth Sounder.

\section{Analisis Data}

Untuk mengetahui sebaran masingmasing parameter di Danau Pandan, hasil data lapang di olah dengan Software Arc Map dengan metode interpolasi. Metode interpolasi yang digunakan yaitu Inverse Data Weigthing (IDW). Metode Inverse Distance Weighted (IDW) merupakan metode deterministik yang sederhana dengan mempertimbangkan titik disekitarnya (NCGIA, 1997). Asumsi dari metode ini adalah nilai interpolasi akan lebih mirip pada data sampel yang dekat daripada yang lebih jauh. Bobot (weight) akan berubah secara linear sesuai dengan jaraknya dengan data sampel. Bobot ini tidak akan dipengaruhi oleh letak dari data sampel (Pramono, 2008).

\section{HASIL DAN PEMBAHASAN}

Parameter fisika air danau yang diamati pada penelitian ini adalah mengetahui data sebaran suhu dan kedalaman perairan danau pandan. Hasil pengukuran suhu air yang dilakukan secara in situ pada perairan danau pandan. Hasil pengukuran suhu disajikan pada Gambar 2 dengan data suhu terendah 32,0 ${ }^{\circ} \mathrm{C}$ dan suhu tertinggi sebesar $36,0{ }^{\circ} \mathrm{C}$.

Hasil pengukuran sampel air yang telah dikompositkan bagian permukaan dan dasar pada danau pandan menunjukkan bahwa suhu air di perairan Danau dari titik 1 sampai titik 10 berkisar antara $32-36^{\circ} \mathrm{C}$. Nilai suhu pada Titik 4 dengan Titik 3 dan Titik 6 yang memiliki selesih 0,1 dan 0,3 memiliki suhu lebih tinggi dibandingkan titik yang lain. 


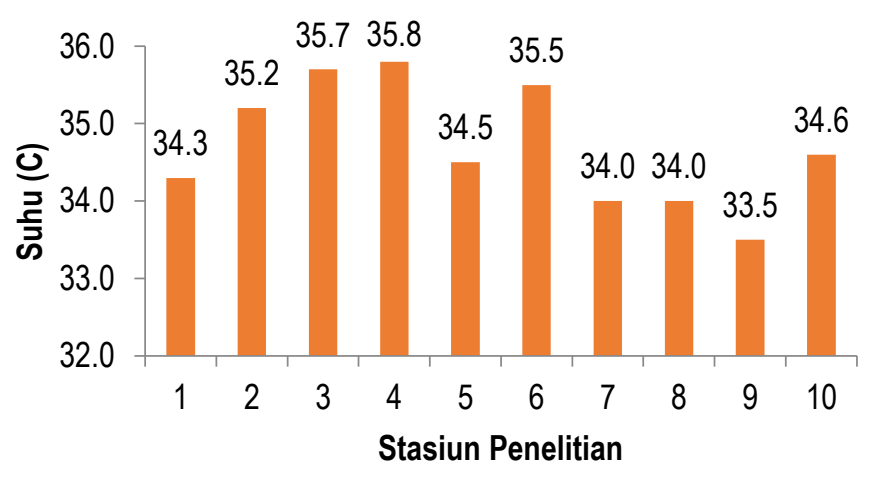

Gambar 2. Grafik Suhu Perairan Danau Pandan

Perbedaan suhu pada perairan danau pandan disebabkan oleh intensitas cahaya matahari, kanopi dari vegetasi sekitar perairan serta pertukaran panas antara air dengan udara di sekelilingnya. Danau relatif tidak terstratifikasi apabila intensitas radiasi matahari cukup rendah dan hembusan angin yang kuat (Berdasarkan hasil interpolasi (Gambar 3) terlihat jelas bahwa suhu air yang lebih rendah terdapat pada daerah yang dialiri oleh sungai dan parit-parit disekitar danau.

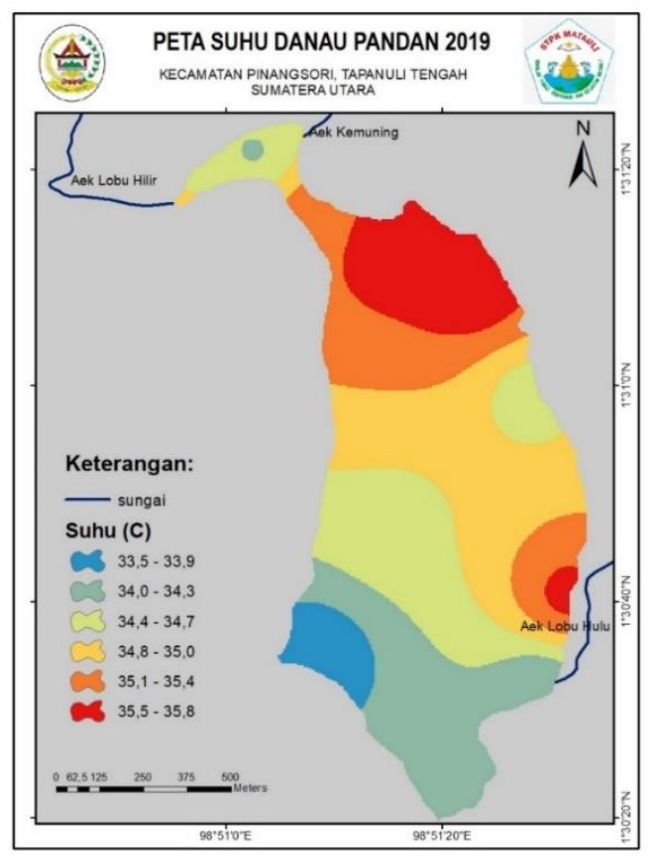

Gambar 3. Suhu Perairan Danau Pandan
Peristiwa pengadukan suhu danau pandan pada daerah epililimnion maupun hipolimnion dapat terbentuk. Proses difusi terjadi pada daerah peralihan antara epilimnion dengan hipolimnion dan daerah hipolimnion dengan sedimentasi dasar danau. Ali (2017) menyatakan bahwa kondisi stratifikasi danau akan terjadi jika intensitas radiasi matahari cukup tinggi dan hembusan angin relatif rendah. Angin yang bertiup di atas permukaan akan membangkitkan tekanan terhadap permukaan air dan besaran ini selanjutnya akan membangkitkan energi kinetik turbulen di bawah permukaan air.

Menurut Peraturan Pemerintah nomor 82 tahun 2001 tentang pengelolaan kualitas air dan pengendalian pencemaran air, suhu danau Pandan termasuk Deviasi 3 dengan nilai 0,80. Standar deviasi temperatur danau pandan merupakan kondisi alamiah yang terjadi pada saat pengujian.

Suhu merupakan salah satu faktor yang sangat penting dalam proses metabolisme organisme di perairan. Suhu air mempunyai peranan dalam mengatur kehidupan biota perairan, terutama dalam proses metabolisme. Kenaikan suhu menyebabkan terjadinya peningkatan konsumsi oksigen, namun di lain kondisi juga mengakibatkan turunnya kelarutan oksigen dalam air. Oleh karena itu, maka pada kondisi tersebut organisme akuatik seringkali tidak mampu memenuhi kadar oksigen terlarut untuk keperluan proses metabolisme dan respirasi. 


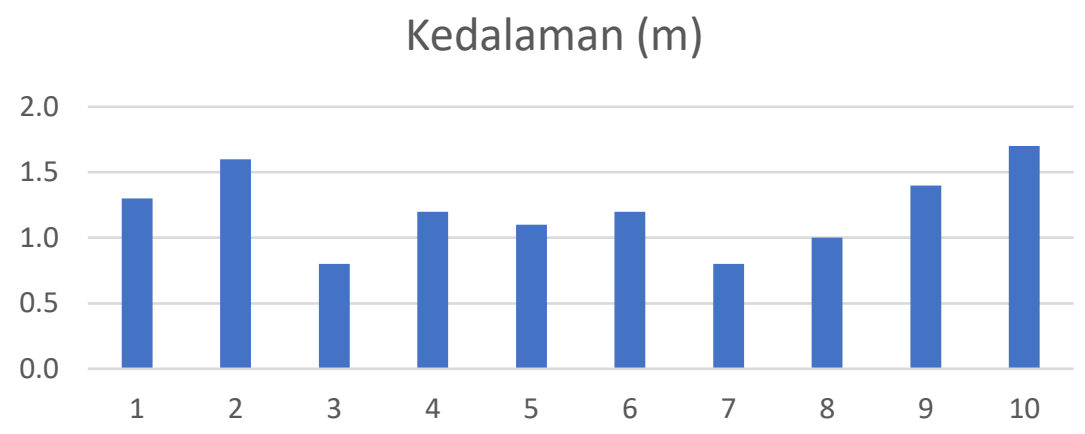

Gambar 4. Grafik kedalaman Perairan Danau Pandan

Perubahan suhu yang mendadak atau kejadian suhu yang ekstrim akan mengganggu kehidupan organisme bahkan dapat menyebabkan kematian. Stratifikasi merupakan salah satu indikator kestabilan danau. Semakin kuat stratifikasi, maka semakin stabil perairan suatu danau. Kestabilan dianggap penting karena bisa menjadi penggerak utama dinamika biota air seperti fitoplankton (Yang et al. 2016). Kekuatan stratifikasi akan melemah ketika transfer energi panas dari cahaya matahari ke badan air memiliki intensitas rendah (Magee dan Wu, 2017).

Kedalaman danau pandan dari 10 titik lokasi yang diujikan sekitar $0,8 \mathrm{~m}-$ 1,7 m dapat dilihat pada Gambar 4. Kedalaman yang dimiliki oleh danau pandan termasuk kedalam kategori danau yang dangkal jika dibandingkan danau danau lain yang telah diteliti sebelumya. Danau siombak yang juga terdapat di provinsi sumatera utara, tetapi telatak di kota medan, diketahui bahwa danau siombak memiliki kedalaman maksimum $5 \mathrm{~m}$ saat pasang dan $4 \mathrm{~m}$ saat surut (Muhtadi et al. 2016).

Berdasarkan hasil interpolasi (Gambar 5) terlihat jelas bahwa kedalaman danau pandan terendah dapat dilihat pada arah selatan yang salah satunya terdapat pada aliran air sungai aek lobu. Aldama et al. (2013) dan Barroso et al. (2014) menyatakan kedalaman danau berpengaruh sangat besar terhadap kualitas air. Faktor kedalaman suatu danau memiliki keterkaitan juga dengan adanya peristiwa pengadukan di danau. Sekeliling permukaan danau pandan banyak ditumbuhi oleh tanaman pandan duri (Pandanus Tectorius). Sedangkan dasar perairan danau pandan yaitu sedimentasi berlumpur dan hampir seluruh dasar dasar danau ditumbuhi oleh makroalga dari jenis Hydrilla Verticillata. Danau pandan mengalami eutrofikasi yang diduga berasal dari beberapa limbah pertanian maupun aktivitas manusia yang berada disekitar danau yang mengandung senyawa nitrogen dan fosfat. Marthana et al (2014) nitrogen dan fosfat dapat memicu pertumbuhan yang tidak terkontrol / blooming hydrilla, blooming hydrilla menganggu aktivitas danau rawapening sebagai pengedaliana banjir, perikanan dan kegiatan wisata.



Gambar 5. Layout Peta Kontur Danau Pandan

Parameter kimia air danau yang diamati pada penelitian ini adalah 
mengetahui data sebaran $\mathrm{pH}$ dan kandungan oksigen terlarut atau DO (Dissolved Oxygen) danau pandan. Berdasarkan hasil pengamatan dilapangan, $\mathrm{pH}$ air danau Pandan berkisar antara $6,8-9,02$. Kadar $\mathrm{pH}$ tertinggi terdapat pada stasiun 7 , hal ini dikarenakan pada stasiun 7 merupakan titik dimana sumber air danau Pandan. Adanya serasah - serasah yang merupakan bahan organik jatuh di Sungai Aek Lobu dibawa masuk ke danau Pandan sehingga $\mathrm{pH}$ pada stasuin tersebut terlihat tinggi. Hal ini juga dapat dilihat dari peta sebaran $\mathrm{pH}$ danau Pandan yang disajikan pada Gambar 6 . Yuningsih et al (2014) menyatakan komposisi bahan organik dapat menyebabkan meningkatnya $\mathrm{pH}$ air, hal ini dapat diterjadi karena pada proses dekomposisi bahan organik.

Hal ini menunjukkan bahwa perairan Danau Pandan memiliki nilai $\mathrm{pH}$ yang masih termasuk dalam kisaran normal berdasarkan PP No. 82 Tahun 2001 dengan baku mutu $6-9$. Kondisi perairan yang memiliki $\mathrm{pH}$ netral sangat baik bagi ekosistem air dan baik untuk pertumbuhan dan perkembangan organisme perairan. Tinggi atau rendahnya nilai $\mathrm{pH}$ air tergantung pada beberapa faktor seperti: konsentrasi gas gas dalam air seperti $\mathrm{CO}_{2}$, konsentrasi garam-garam karbonat dan bikarbonat dan proses dekomposisi bahan organik di dasar perairan. Secara alamiah, $\mathrm{pH}$ perairan dipengaruhi oleh konsentrasi karbondioksida $\left(\mathrm{CO}_{2}\right)$ dan senyawa bersifat asam. Perairan umum dengan aktivitas fotosintesis dan respirasi organisme yang hidup didalamnya akan membentuk reaksi berantai karbonat karbonat. Sebaran derajat keasaman Danau Pandan dapat dilihat pada Gambar 7. Sebaran $\mathrm{pH}$ danau pandan pada gambar tersebut diketahui bahwa $\mathrm{pH}$ tertinggi terletak didekat pada aliran sungai Aek Lobu Hilir. Tinggi nya $\mathrm{pH}$ dikarenakan banyaknya serasah-serasah di sunga Aek Lobu Hilir dan mengalir ke dalam danau Pandan.



Gambar 6 Grafik pH Perairan Danau Pandan 


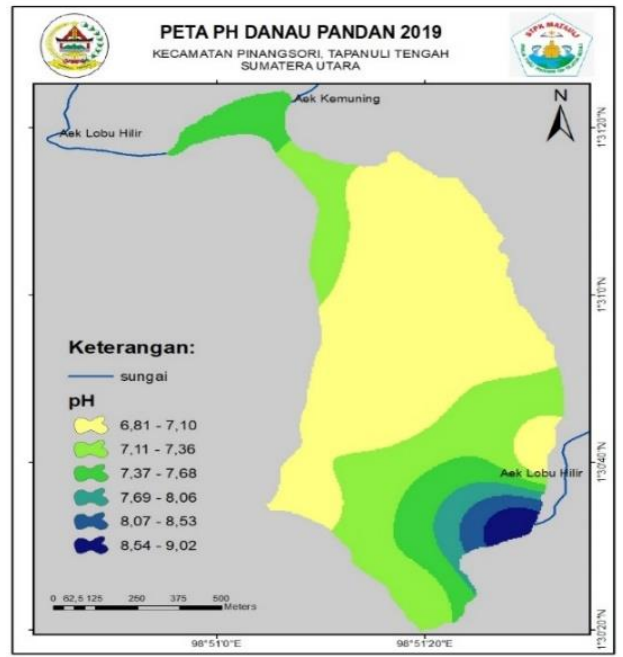

Gambar 7. pH Perairan Danau Pandan

\section{Oksigen terlarut (Dissolved} Oxygen $=$ DO) dibutuhkan oleh semua jasad hidup untuk pernapasan, proses metabolisme atau pertukaran zat yang kemudian menghasilkan energi untuk pertumbuhan dan pembiakan. Disamping itu, oksigen juga dibutuhkan untuk oksidasi bahan- bahan organik dan anorganik dalam proses aerobik. Sumber utama oksigen dalam suatu perairan berasal sari suatu proses difusi dari udara bebas dan hasil fotosintesis organisme yang hidup dalam perairan tersebut (Salmin, 2005).

Kecepatan difusi oksigen dari udara, tergantung sari beberapa faktor, seperti kekeruhan air, suhu, salinitas, pergerakan massa air dan udara seperti arus, gelombang dan pasang surut. Pada lapisan permukaan, kadar oksigen akan lebih tinggi, karena adanya proses difusi antara air dengan udara bebas serta adanya proses fotosintesis. Hasil yang diperoleh dari pengukuran DO air, dapat dijelaskan bahwa nilai DO air danau Pandan yang ditemukan di setiap stasiun penelitian memperlihatkan variasi yang menyolok dengan kisaran antara 4,91 $\mathrm{mg} / \mathrm{L}-9,03 \mathrm{mg} / \mathrm{L}$. Nilai DO air tertinggi ditemukan pada stasiun ke-1 sebesar 9,03 $\mathrm{mg} / \mathrm{L}$ dan nilai DO terendah ditemukan pada stasiun ke-10 sebesar 4,91 mg/L. Grafik perubahan DO pada setiap pengambilan dapat dilihat pada Gambar 8.

Sebaran Oksigen Terlarut pada perairan Pandan di sajikan pada Gambar 9. Terlihat jelas pada perairan yang memiliki kedalaman yang lebih rendah memiliki DO yang lebih tinggi, hal ini dikarenakan penetrasi cahaya yang masuk keperairan lebih banyak hingga sampai kedasar perairan yang tumbuhi tanaman air seperti Hydrilla verticilata yang banyak ditemukan di danau Pandan. Oksigen yang terlarut di dalam perairan sangat dibutuhkan untuk proses respirasi, baik oleh tanaman air, ikan, maupun organisme lain yang hidup di dalam air, Supratno (2006).



Gambar 8 Grafik Oksigen Terlarut Danau Pandan 


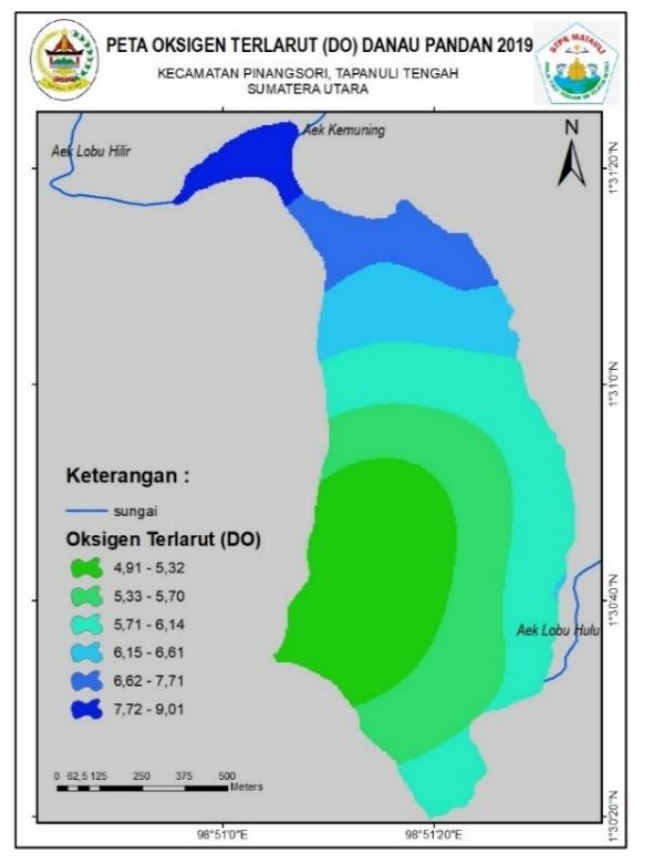

Gambar 9 Oksigen Terlarut Perairan Danau Pandan

Semakin dalamnya danau, maka dapat menurunkan kadar oksigen terlarut, karena proses fotosintesis semakin berkurang dan kadar oksigen yang ada banyak digunakan untuk pernapasan dan oksidasi bahan-bahan organik dan anorganik. Keperluan organisme terhadap oksigen relatif bervariasi tergantung pada jenis, stadium dan aktifitasnya. Sinaga et al. (2016) menyatakan distribusi oksigen terlarut (mg/l) secara vertikal selama 24 jam menghasilkan semakin dalam danau kelapa gading maka semakin rendah kadar oksigen terlarutnya.

Kondisi hidrologi Danau Pandan dibentuk oleh aliran pari-parit dan sungai yang yang bermuara ke Danau Pandan antara lain: Sungai Aek Kemuning dan Aek Lobu. Sedangkan outlet Danau Pandan secara alami mengalir ke arah utara melalui Sungai Aek Kemuning dan bermuara ke Sitardas, Badiri Tapanuli Tengah.

\section{KESIMPULAN}

Hasil pengukuran suhu air Danau Pandan untuk parameter fisika adalah suhu air pada masing-masing stasiun berkisar antara $32,0{ }^{\circ} \mathrm{C}-36,0{ }^{\circ} \mathrm{C}$ dan kedalaman danau pandan kisaran $0,8 \mathrm{~m}-$ $1,7 \mathrm{~m}$. Parameter kimia yang diamati dari kadar oksigen terlarut (DO) air danau Pandan memperlihatkan variasi yang menyolok dengan kisaran bantara 4,91 $\mathrm{mg} / \mathrm{L}-9,03 \mathrm{mg} / \mathrm{L}$, sedangkan $\mathrm{pH}$ air danau Pandan berkisar antara 6,8 - 9,02. Inlet hidrologi Danau Pandan adalah aliran pari-parit dan sungai yang yang bermuara ke danau (sungai Aek Kemuning dan Sungai Aek Lobu) dan outlet danau pandan secara alami mengalir ke arah utara melalui Sungai Aek Kemuning dan bermuara ke Sitardas, Badiri Tapanuli Tengah.

\section{UCAPAN TERIMA KASIH}

Ucapan terima kasih terutama ditujukan kepada Badan Perencanaan Pembangunan Daerah (BAPPEDA) Tapanuli Tengah sebagai donatur dan mitra Sekolah Tinggi Perikanan dan Kelautan (STPK) Matauli, sehingga penelitian ini dapat dilakukan.

\section{DAFTAR PUSTAKA}

Adeleke, A.R., Daud, N., Amimul, A., and Pradhan, R. (2014). Water quality assessment of UPM Lake and the impact of geographic information system. Journal Science Publishing Group, (2), 158-162. https://doi.org/10.11648/ j.ijema.20140203.15.

Aldama, G.R., Palafox, J.T.P., Cruz, L.F.G., Hernández, D.O., Díaz, J.A., Arredondo-Figueroa, J.L. (2013). Morphometric Characteristics of Tropical Shallow Reservoir Used for Aquaculture and Agriculture in the Mexican Plateau. Revista Bio Ciencias,(22), 83-88.

Ali, F. (2017). Tinjauan Limnologis Permasalahan dan Solusi Perairan Darat Indonesia Cetakan ke I. Pusat Penelitian Limnologi LIPI. Cibinong Science Center Botany Garden. Bogor. 
Barroso, G.F., Gonçalves, M.A., Garcia, F.D.C. (2014). The Morphometry of Lake Palmas, A Deep Natural Lake in Brazil. PLoS ONE, (9), e111469.https://doi.org/10.1371/j ournal.pone.0111469.

BPS Kabupaten Tengah. (2018). Kabupaten Tapanuli Tengah dalam Angka 2018. Katalog BPS: 1102001.1024

Bengtsson, L., Fortin, V., Gronewold, A.D., Tanino, Y., Surridge, B., Watson, N., Herschy, R.W. (2012). Water Quality in Lakes and Reservoirs. Encyclopedia of Earth Sciences Series, 883-888.

Kutics, K. (2019). Evolution of water quality of Lake Balaton. Ecocycles. (5),44-73. http://doi. org/10.19040/ecocycles.v5i2.149.

Krismono., Astuti, L.P., Sugianti, Y. (2009). Karakteristik Kualitas Air Danau Limboto, Provinsi Gorontalo. Jurnal Litbag Perikanan Indonesia, (15), 59-68. http://dx.doi.org/10.15578/jppi.15 .1.2009.59-68.

Magee, M.R., Wu, C.H. (2017). Response of water temperatures and stratification to changing climate in three lakes with different morphometry. Hydrology and Earth System Sciences, (21), 6253-6274. https://doi.org/10. 5194/hess-21-6253-2017.

Marthana, W.S.M., Soeprobowati, T.R., Izzati M. (2014). Bioakumulasi Timbal (PB) oleh Hydrilla verticillate L.f. Royle di Danau Rawapenig, Ambarawa Semarang. Jurnal Sains dan Matematika, (22), 52-59.

Muhtadi, A., Yunasfi., Leidonald, R., Sandy, S.D., Junaidy, A., Daulay, A.T. (2016). Status Limnologis Danau Siombak, Medan, Sumatra Utara. Oseanologi dan Limnologi di Indonesia.(1), 39-55. https://doi.org/10.14203/oldi.2016 .v1i1.16

NCGIA. (2007). Interpolation: Inverse Distance Weighting.

http://www.ncgia.ucsb.edu/pubs/ spherekit/inverse.html (Juni 2019).

Pemerintah Kabupaten Tapanuli Tengah. (2020). Wisata Alam Pegunungan. http://www.tapteng.go.id/pariwisa ta.html?id=Wisata_Alam_Pegunu ngan

Peraturan Pemerintah Republik Indonesia Nomor 82 Tahun 2001. Pengelolaan Kualitas Air dan Pengendalian Pencemaran Air.

Pramono, G.H. (2008). Akurasi Metode IDW dan Kriging Untuk Interpolasi Sebaran Sedimen Tersuspensi Di Maros, Sulawesi Selatan. Forum Geografi. (22), 145-158. https://doi.org/10.23917/ forgeo.v22i2.4988.

Salmin. (2005). Oksigen Terlarut (DO) dan Kebutuhan Oksigen Biologi (BOD) Sebagai Salah Satu Indikator Untuk Menentukan Kualitas Perairan. Oseana,(30), 21-26.

Sinaga, E.L.R., Muhtadi, A., Bakti, D. (2016). Profil Suhu, Oksigen Terlarut, dan $\mathrm{pH}$ Secara Vertikal Selama 24 Jam di Danau Kelapa Gading Kabupaten Asahan Sumatera Utara. OmniAkuatika,(12), $114 \quad-\quad 124$ https://doi.org/10.20884/1.oa.201 6.12.2.107

Supratno, K.P.T. (2006). Evaluasi Lahan Tambak Wilayah Pesisir Jepara untuk Pemanfaatan Budidaya Ikan Kerapu. Tesis. Semarang: Program Studi Megister Manajeman Sumberdaya Pantai Program Pasca Sarjana Universitas Diponegoro.

Sulfikar, (2013). Survei Kualitas Air Danau Arena Dayung Tanjung 
Bunga. Jurnal Sainsmat, (2), 3251. https://doi.org/10.35580/sains mat217542013.

Petri, M. (2006). Water Quality of Lake Constance. Springer- Verlag Berlin Heidelberg. (pp 127-138). https://doi.org/10.1007/698_5_01 8.

Wijaya, D., Samuel., Masak, P.R.P. (2009). Kajian Kualitas Air dan Potensi Produksi Sumber Daya Ikan Di Danau Towuti, Sulawesi Selatan. Jurnal Bawal,(2) , 291297. http://dx.doi.org/10.15578/ bawal.2.6.2009.291-297. .

Yang, Y., Colom, W., Pierson, D., Pettersson, K. (2016). Water column stability and summer phytoplankton dynamics in a temperate lake (Lake Erken, Sweden). Journal Inland Waters, (6), 499-508. https://doi.org/ 10.1080/IW-6.4.874.

Yuningsih, H.D., Soedarsono, P., Anggoro, S. (2014). Hubungan Bahan Organik Dengan Produktivitas Perairan pada Kawasan Tutupan Eceng Gondok, Perairan Terbuka dan Keramba Jaring Apung di Rawa Pening Kabupaten Semarang Jawa Tengah. Jurnal Maquares Diponegoro, (3), 37-43. 
